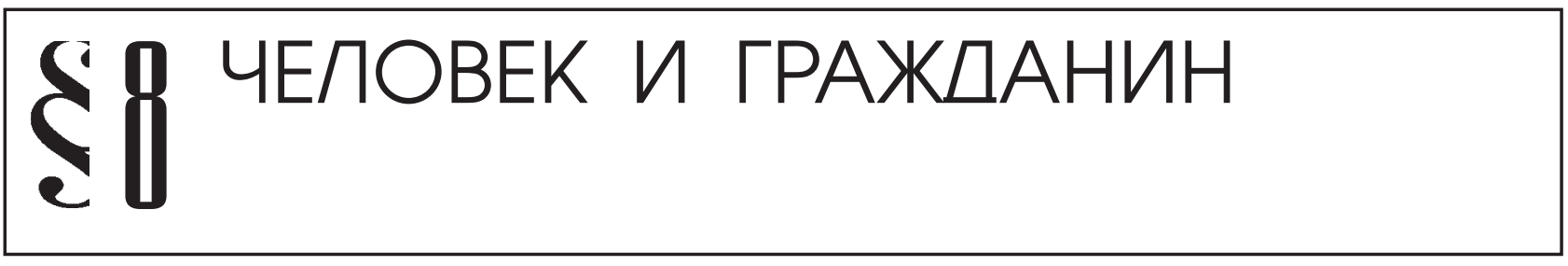

Кананыкина Е.С.

\title{
ЮРИДИЧЕСКИЕ ФОРМЫ ИСТОЧНИКОВ ПРАВА ОБ ОБРАЗОВАНИИ В СОЦИАЛИСТИЧЕСКОЙ СИСТЕМЕ КИТАЙСКОЙ НАРОДНОЙ РЕСПУБЛИКИ
}

\begin{abstract}
Аннотация: Современный Китай уделяет огромное внимание реформе управления систе-мой образования и регулирования его структуры, а именно распространению базового, сдерживанию общего и усилению специального и среднего технического образования. Специфика экономического и социального развития и, как следствие этого, иной уровень грамотности занятого населения (соответственно 9 и 6 классов в городе и на селе) приводят к принципиально иному соотношению образования общего и профессионального. Если в развитых европейских странах уже ста-вится задача их сплава на базе всеобщего полного среднего образования, то в Ки-тае в течение еще довольно длительного времени они будут сосуществовать как разные «потоки».

Review: Modern China is paying much attention at the reform of managing the system of education and regulation of education structure, in particular, promotion of the basic education, restriction of general education and improvement of vocational and secondary technical education. Peculiarities of economic and social development and, consequently, another level of professional competence of employed population (compared to the 9th and 6tth grades in a city and a village) create a completely different relation between general education and vocational training. While European countries already aim at unifying these and creating a general full secondary education, in China they will be existing as two different 'flows' for quite a long period of time.
\end{abstract}

Ключевые слова: Юриспруденция, Китай, образование, система, политика, право, законодательство, источники, обучение, акты

Keywords: law studies, China, education, system, politics, law, legislation, sources, education, acts.

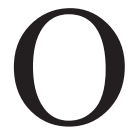

бщеизвестно, что право на образование гарантируется, прежде всего, основным законом страны, в частности, Конституцией КНР 1982 г., одна из статей корой гласит: «Граждане Китайской Народной Республики имеют право на образование. Это право граждан государство обеспечивает посредством создания и постоянного расширения различных учебных заведений» (ст. 19 и 46) 1 .

После продолжительного периода «культурной революции», которая нанесла большой ущерб просвещению КНР, в 1982 г. руководство страны предприняло ряд мер, направленных на возрождение и

${ }^{1}$ Клепиков В.3. Развитие общеобразовательной школы КНР // Педагогика. - 1988. № 9. совершенствование системы образования. Третий Пленум ЦК КПК XI созыва 1978 2. наметил пути решения вставших перед страной сложных проблем образования. В соответствии с установками Пленума, закрепленными и развитыми XII съездом КПК 1982 г. началось осуществление масштабных преобразований.

В большинстве районов страны профессиональные школы действуют на уровне неполных средних, или даже начальных школ, т.е. неполные, средние профессиональные школы становятся одним из путей распространения всеобщего среднего образования ${ }^{2}$. Не менее важный шаг

\footnotetext{
${ }^{2}$ Боревская Н.Е. Новые учебные программы в КНР // Совет-
} ская педагогика. - 1993. № 3. 
- реформа внутри самой системы образования: изменение учебных планов и программ, сроков $u$ методов обучения. Она была провозглашена в Постановлении ЦК КПК и Госсовета КНР «О реформе системы образования" от 27.05.1985 2., которое предусмотрело осуществление коренной комплексной реформы всей сферы просвещения и подготовки кадров по следующим основным направлениям:

1. передача местным органам власти ответственности за развитие начального образования,

2. постепенное обеспечение всеобщего обязательного 9-летнего образования,

3. упорядочение структуры среднего образования,

4. всемерное развитие профессионально-технического обучения,

5. изменение плана приема в высшее учебное заведение,

6. совершенствование системы распределения выпускников вузов,

7. расширение самоуправленческих начал в деятельности вуза,

8. кардинальное улучшение управления народным образованием.

Реализация намеченных мер призвана обеспечить повышение образовательного и культурного уровня народа и подготовку необходимого числа квалифицированных специалистов ${ }^{3}$.

В данном решении говорилось: «Места несут ответственность за развитие и осуществление базового образования, управление учебными заведениями осуществляется по ступеням. В основе реформы административного управления лежит принцип «на разных уровнях создавать школы, на разных уровнях управлять школами».

На практике это выглядело следующим образом: «Ключевые учебные заведения, т.е. имеющие наилучшую материально-техническую базу, педагогический коллектив и т.п., находятся в непосредственном подчинении органов образования провиничий, автономных районов и городов ичентрального подчинения (Пекин, Шанхай). На селе создание школ ведется на трех уровнях (уезд, волость, деревня), а управление ими - на двух (ибо деревни не имеют властных структур) $)^{4}$.

\footnotetext{
3 Жэньминь жибао. - 1985. 29 мая.

${ }^{4}$ Боревская Н.Е. Управление образованиям в Китае // Педагогика. - 1996. № 11.
}

Это означает, что уезды создают обычные и профессиональные полные средние школы (либо отдельно школы II ступени), экспериментальные начальные школы, курсы повышения квалификации учителей, а также свой аппарат управления образованием. Неполные средние и начальные школы переведены в подчинение волости. Именно на волость возложена ответственность за осуществление базового неполного 9-летнего среднего образования.

Проведение подобной политики было обусловлено различными причинами, одна из них - быстро растущее количество школ, в результате чего в ведении волости сегодня находится такое число учебных заведений, которое раньше приходилось на уезд. Вот почему в середине 1980-х гг. в волостных правительствах были созданы Cоветы по управлению образованием, куда вошли: начальник волости, директор волостной полной средней школь, директор центральной начальной школь (центральная школа не только является образцовой, но, прежде всего, служит базой распространения передового опыта, здесь проходят семинары, совещания), начальник финансового управления, руководители хозяйств.

На волостях лежит обязанность по сбору средств на развитие образования. Как было сказано ранее, плата за обучение с учащихся не взималась в соответствии с требованиями Закона «Об обязательном 9-летнем обучении».

Закон 1986 г. санкционировал также создание учебных заведений на средства предприятий, ведомств, общественных организаций.

Вместе с тем, многие волостные правительства были не удовлетворены разделением управленческих функций, поскольку вся реальная власть осталась у уездов. Создание волостных комитетов образования, которые находились бы в прямом подчинении уездных комитетов, а также наделение их правом реального управления всеми школами волости, включая кадровые вопросы, финансирование и административное управление образованием помогло бы нивелировать разногласия между уровнями власти. В обязанности волостного комитета предполагалось включить составление планов развития образования, улучшение материальных условий школ, контроль их работы, организацию найма и профессиональной подготовки учителей. 


\section{Политика и общество 9 (105) • 2013}

Закон КНР «Об обязательном образовании» принятый 4-й сессией Всекитайского собрания народных представителей шестого созыва 12.04.1986 г., был разработан на основании Конституции КНР с учетом текущих политических изменений в стране в целях развития базового образования, содействия строительству социалистической материальной и духовной культуры ${ }^{5}$.

Со времени принятия Закона «Об обязательном обучении» была приложена масса усилии для реализации 9-летнего обязательного обучения, поскольку на первом этапе, в 1980-е гг, обязательным было лишь начальное обучение, и только с начала 1990-х г. - 9-летнее. К концу 2000 г. им было охвачено 85 процентов населения ${ }^{6}$.

Конкретные меры по распространению обязательного образования принимаются провинциями, автономными районами и городами центрального подчинения в зависимости от экономического и культурного развития данного района.

Обязательное образование, говорится в ст. 3 Закона, должно воплотить курс государства в области образования, содействовать всемерному повышению качества обучения, всестороннему нравственному, умственному и физическому развитию детей и подростков, заложить основу для совершенствования морального облика нации, воспитания высоконравственных, культурных, дисциплинированных строителей социализма.

Государство, общество, школа и семья обеспечивают право детей и подростков соответствующего возраста на получение обязательного образования без различий пола, национальности и вероисповедания. Закон гарантирует каждому ребенку по достижении 6-летнего возраста поступать в школу и получать обязательное образование в соответствии со своим возрастом.

В районах, где еще не созданы необходимые условия, возраст поступления в школу может быть установлен с 7 лет. Школы обязаны содействовать распространению и внедрению по всей стране общегосударственного языка $n y$ -

\footnotetext{
5 Чжунхуа жэньминь гунхэго гоуюань гунбао. - 1986. № 12 .

6 Реморенко И. Модернизация по-китайски: дешевый рынок для всех и дорогая свобода для элиты.// Педагогический Вестник. 1-30 апреля 2004. № 7-8 (334-335).
}

mунхуа. Школы, осуществляющие набор учащихся в основном из представителей национальных меньшинств, могут вести обучение на языке и использовать письменность национальных меньшинств (ст. 6).

Согласно документу обязательное обучение делится на два этапа: начальное и неполное среднее образование, сроки обучения на которых в большинстве случаев соотносятся как $6: 3$, а в определенной части учебных заведений как 5:4. Она дополняется трехгодичной старшей средней школой.

Введение всеобщего неполного среднего образования осуществляется на базе всеобщего начального образования. Срок обучения в начальных и неполных средних школах определяется структурным подразделением Государственного Совета (Госсовета), ведающим образованием.

Ответственность за введение обязательного образования несут местные власти под руководством Госсовета; его же структурное подразделение в зависимости от потребностей социалистической модернизации, а также физического и духовного развития детей и подростков, устанавливает сроки обязательного обучения, содержание учебного процесса, учебные программы и пособия.

Местные народные представительства различных ступеней обязаны рационально размещать начальные и неполные средние школы, обеспечивать их близость к местожительству детей и подростков. Планы развития, составляемые на местах, должны включать меры по ведению обязательного образования.

Одной из гарантий предоставления обязательного обучения с введением в действие Закона явилось право бесплатного обучения. Так, к примеру, государство устанавливает стипендии, помогает нуждающимся учащимся получить образование. Расходы по осуществлению обязательного образования и средства, предназначенные на капитальное строительство в области образования, изыскиваются Гососветом и местными народными правительствами различных ступеней и должны быть ими обеспечены (ст. 10).

Ассигнования, предназначенные для осуществления обязательного образования, производимые государством, должны пропорционально превышать доходы и увеличиваться соответ- 
ственно расходам на образование в зависимости от численности учащихся.

Местные народные правительства различных ступеней согласно Постановлению Госсовета собирают в городе и деревне дополнительный налог, который используется, главным образом, для осуществления обязательного образования. Государство также выделяет дополнительные средства районам, испытывающим экономические трудности, для осуществления указанной цели.

Местные народные правительства ведут воспитательную работу с родителями либо опекунами детей и подростков соответствующего возраста, не посещающих школу, кроме больных, увечных и тех, кто может не учиться в силу особых обстоятельств и с согласия местного народного правительства, а также принимают эффективные меры, чтобы заставить родителей либо опекунов отправить учиться своих детей либо подопечных. В воспитательных целях они также работают с организациями и частными лицами, если те принимают на работу детей и подростков соответствующего возраста, пресекая подобные действия. При особо грубых нарушениях применяются такие меры, как штраф, приостановление деятельности предприятия либо аннулирование патента.

Одна из примет современной образовательной политики КНР - усиление внимания к предметам естественно научного цикла. При Государственном комитете КНР по образованию создан специальный совет, разрабатывающий проект изучения естественнонаучных дисциплин на всех ступенях.

В отличие отряда развитых стран Запада Китай все прошлые десятилетия был известен повышенным вниманием к преподаванию математики. Специальная комиссия при Китайском педагогическом Свете провела исследования соответствия курсов математики в школах запросам различных профессий и институтской специализации и пришла к выводу, что все разделы арифметики следует оставить в силу их актуальности для всех специальностей, а некоторые традиционные разделы алгебры, стереометрии, аналитической геометрии имеют довольно избирательное применение, материалы по информатике, статистике, теории вероятности, дифференциальному и инте- гральному исчислению, по методам оптимального поиска и единого планирования, по линейному программированию, векторному анализу, начертательной геометрии должны дополнить программы. В начальной школе увеличен объем разделов по алгебре и геометрии, изучение математики в полной средней школе приобрело многоуровневый характер: наиболее важные разделы включены в состав обязательных дисциплин, а углубленные знания распределены по факультативным занятиям ${ }^{7}$.

Значительно увеличено время обучения по курсам: естествознания и биологии; изменена методика преподавания, усилена экспериментальная база, процесс приобретения знаний увязан с производственно-техническим обучением, с проблемами народонаселения, охраной окружающей среды, генетикой, цитологией, экологией.

Авторы новых программ учли также мировые тенденции гуманитаризации обучения - в средней школе увеличен объем гуманитарного цикла, в частности истории, а в обязательной школе усиливается внимание к музыкальному, эстетическому, трудовому воспитанию. Иностранный язык введен со 2-го года обучения в младшей средней школе как факультатив.

Несмотря на указанные выше значительные достижения к началу 1990-х гг. Китай являлся второй после Индии страной в мире по числу неграмотных ${ }^{8}$.

Согласно докладу, представленному Китаем на 42-й сессии МКО (Международный комитет по образованию), 9-летнее обязательное образование введено в городской местности и в развитых районах вдоль морского побережья 9 . В других районах страны обязательное начальное образование только вводится. В наиболее экономически отсталых районах принимаются программы для введения 3-4-летнего обязательного обучения.

В соответствии с разработанным Планом по ликвидации неграмотности, начиная с 1990 г. число неграмотных должно ежегодно уменьшать-

\footnotetext{
${ }^{7}$ Путун цзяоюй гайгэ. - Пекин, 1987. - С. 36-72.

${ }^{8}$ The Development of Education in China. 1988-1990. - Bejing, State Education Commission, 1990. - P. 10.

${ }^{9}$ Unesco. Compendium of Statistics on Illiteracy - 1990 Edition. P. 13, 25, 37; - Unesco. Statistical Yearbook, 1989. Table 1.3. P. 1-19.
} 


\section{Политика и общество $9(105) \cdot 2013$}

ся на 4 млн. человек. В числе приоритетных групп - женщины, национальные меньшинства и неграмотные, проживающие в районах с наименее благоприятными условиями.

По признанию большинства специалистов, сегодняшние выпускники школ ни по моральным качествам, ни по идеологическим убеждениям, ни по уровню физического и интеллектуального развития не отвечают требованиям рыночной экономики и цивилизованного общества. Нижеследующая формулировка достаточно исчерпывающе раскрывает позицию педагогов в КНР: «Нужно усиливать и гражданское воспитание, и научное мировоззрение, воспитывать гармоничную здоровую личность, прививать учащимся марксистские политические и экономические знания, утверждать в них понятия социалистической товарной экономики, т.е. понятия стоимости, времени, информации, эффективности, конкуренции, творческую жилку и чувство хозяина. В то же время учебные программы не должны избегать критики тех негативных явлений, которые несут с собой товарные отношения ${ }^{10} \gg$.

Программа развития и реформирования образования в Китае, 1990-х гг. определяет реальные шаги на пути перехода от традиционной и инерционной модели «школа ради вуза» к новой модели повышения образовательного потенциала всего населения.

Новые учебные программы разрабатываются с учетом сегодняшних целей школы, мировых тенденции развития науки, а также потребностей эпохи принципа опережающего развития. Составление принципиально новых учебных планов и программ нельзя рассматривать в отрыве от реформы системы вступительных экзаменов.

В 1994 г. произошел переход от общенациональных вступительных испытаний в любой вуз независимо от профиля (6 экзаменов) к профилированной системе экзаменов в гуманитарные и технические вузы (три общих и один предмет по специальности) с учетом качества аттестата. Вариативность программ вступительных экзаменов связана с необходимостью избавления от унификации школьных программ, быстрого обновления содержания обучения. ${ }^{10}$ Спецвыпуск журнала Вестник Нанкинского педагогиче-
ского университета. - Нанкин, 1989. - С. 58.
После острых дискуссий первой половины 1980-х гг. задачи младшей средней школы видоизменились. После ее включения в состав обязательной «девятилетки», она стала ориентировать учащихся на приобретение профессии, привитие навыков трудовой деятельности. Заложенный фундамент знаний в старшей средней школе углублен и расширен благодаря разделению на потоки.

Закон КНР “Об образовании» от 18.03.1995 2. ${ }^{11}$ закрепляет социалистическую модернизированную систему образования в Китайской Народной Республике, основы статуса участников образовательных отношений, принципы финансирования образовательных учреждений и межгосударственного обмена.

В то же время в Законе отсутствует детальное регулирование образовательных отношений, порядка реализации обучающимися педагогическими и иными работниками представленных им прав и возложенных на них обязанностей. Из Закона невозможно установить даже такой принципиально важный вопрос, как вопрос об уровнях образования, получаемых гражданами КНР на бесплатной основе, за счет государственного бюджета.

В духе лучших социалистических традиций марксизма-ленинизма декларирует свои положения глава 9 «Правовая ответственность». Данной главой устанавливаются разнообразные виды ответственности за нарушение расходования бюджетных средств на образование, нарушение школьного порядка, халатное отношение к государственному имуществу, за взимание платы за обучение, несанкционированное открытие школ, зачислению на обучение сверх нормативов, лоббирование поступлению отдельных студентов, проведение экзаменов нечестным путем и иные нарушения.

Государственный комитет по образованию

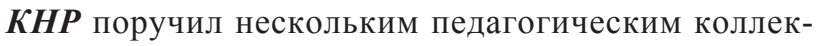
тивам в Ухани и Нанкине разработку программ для неполных 9-летних и старших средних школ. К новым программам выдвигались следующие требования: содействовать развитию, как общества, так

\footnotetext{
${ }^{11}$ Принят на 3-й пленарной сессии Всекитайского Народного собрания. Education Law of the People's Republic of China/ State Education commission of the People's Republic of China. Beijing. 1995.
} 
и отдельной личности; придерживаться принципа опережающего развития; содействовать интеграции и оптимизации системы образования. Они вступили в действие по всей стране в 1998 г.

В 2000 г. в стране была повсеместно введена система обязательного начального образования и устранения неграмотности среди молодого населения и людей среднего возраста, расширено влияние высшего образования, увеличено студенчество с 7 до 16 млн. обучающихся.

Взрослое образование раньше носило название "рабоче-крестьянское образование», или «образование, получаемое во внерабочее время».

В 1990-е гг. с расширением сферы и форм образования, оно официально называется «образование для взрослых», а с 2000-х гг. образование для взрослых включено в состав перманентного образования или образования через всю жизнь.

В 1987 г. китайское правительство постановило, что взрослое образование является основным элементом процесса модернизации страны. Оно представляет собой необходимое условие развития экономики, прогресса науки и техники современного общества.

Традиционно существуют две формы образования для взрослых: предполагающее или не предполагающее получение диплома. Образование без диплома включает в себя ликвидацию неграмотности, обучение практической технике в деревне, предварительное обучение по месту работы, продолжение обучения после окончания вуза и др. Образование с получением диплома включает в себя обучение в университете, институте, колледже, техникуме и школе.

После принятия 27.05.1985 г. Постановления ЦК КПК «О реформе системы образования и создании Комитета по образованию» поставлены большие задачи по дальнейшему развитию педагогической науки.

Как отмечается в Постановлении, с конца 1950 гг. просвещение и педагогическая наука «стали подвергаться нападкам в ходе пличных левацких политических кампаний. «Культурная революция», отвергнувшая необходимость распространения знаний и упразднившая просвещение, довела ошибки до крайности» ${ }^{12}$.

12 Постановление ЦК КПК о реформе системы образования от 27.05.1985 г. // Жэньминь жибао. - 1985. 27 мая.
Начиная с 1986 г. Центральный институт педагогических исследований подготовил и издал большое количество трудов, посвященных вопросам реформы образования, к примеру, книга «Китайская педагогическая наука», в которых представлен анализ процессов ее реализации, как в масштабах всей страны, так и в отдельных регионах, провинциях, крупных городах.

Изучение материалов о состоянии и перспективах развития педагогической науки в КНР на современном этапе свидетельствует, что за довольно короткий период времени, прошедший после разрушительной «культурной революции», здесь достигнуты значительные и ощутимые успехи, практически заново создана широкая сеть научных учреждений в области педагогики.

Китайские педагоги выходят на довольно высокий уровень проведения фундаментальных и прикладных исследований, широко используя опытноэкспериментальную работу в школах.

Современная система ученых степеней КНР была сформирована в 1981 г. Согласно Положению КНР «Об ученых степенях», лицам, оканчивающим полный курс университета или аспирантуру присваивается степень бакалавра, магистра и доктора наук.

В настоящее время среди организаций, имеющих право присваивать степень доктора наук и степень магистра, вузы составляют соответственно 85 процентов докторских степеней, 78 процентов магистерских; 50 процентов вузов присваивают степень бакалавра.

«Программа 211» 1995 г. на сегодняшний день представляет собой крупнейшую по масштабам государственного инвестирования программу развития высшего образования со времени создания КНР.

Это стратегическая программа китайского правительства на рубеже веков. Ее генеральная задача состоит в том, чтобы в период с 1995 по 2000 гг. сосредоточить силы на развитие 100 ведущих вузов, а затем на этой базе добиться того, чтобы эти вузы стали базой подготовки высококвалифицированных специалистов, способных решать вопросы экономического строительства и социального развития.

Осуществление «Программы 211» включает в себя три направления: - развитие ведущих научных направлений, - создание системы общественного обслуживания, - комплексное развитие инфраструктуры вузов. 


\section{Политика и общество 9 (105) • 2013}

Финансовые средства, необходимые для «Программы 211», составляются из инвестиций государства, ведомств, региональных администраций и собственных вложений вузов. Согласно плану на 1996-2002 гг,, строительные и дополнительные инвестиции в общей сумме составили 18.369.000.000 юаней. К 2002 г. реально осуществлены инвестиции на 82 процентов ${ }^{13}$.

Осуществление этой программы дало толчок реформе управления образовательной сферы и произвело переворот в системе управления учебными заведениями. Заметно улучшились учебные условия и общая атмосфера подготовки творческих высококвалифицированных специалистов. Оптимизировалась научно-исследовательская структура, поднялся уровень оснащения учебным и научно-исследовательским оборудованием и уровень научно-исследовательских возможностей в высших учебных заведениях.

На высшее образование в Китае возлагается двойная задача: подготовка высококвалифицированных специалистов и развитие науки и техники страны.

На данном уровне образования продолжает действие Временное положение об организации обычных высших учебных заведений, опубликованное Госсоветом КНР 15.12.1986 г. ${ }^{14}$, разработанное в целях улучшения управления высшим образованием, обеспечения качества образования в обычных высших учебных заведениях, стимулирования планомерного и пропорционального развития высшего образования.

Высшие учебные заведения в настоящем Положении представлены университетами с дневной формой обучения, куда принимаются выпускники средних школ высшей ступени по результатам специально разработанных государственных экзаменов, а также отраслевые институты, ускоренные высшие учебные заведения, высшие профессиональные учебные заведения. Вопросы, связанные с созданием обычных высших учебных заведений, решаются Государственным комитетом по делам образования.

Государственный комитет по делам образования в соответствии с потребностями экономи-

\footnotetext{
13 Чжан Лили. Состояние китайского высшего образования // Высшее образование в России. - 2002. № 5.

14 Чжунхуа жэньминь гунхэго гоуаюань гунбао. - 1987. № 4.
}

ческого строительства и социального развития, на основании научных подходов к подготовке необходимых специалистов и с учетом реальных возможностей в обеспечении учебного процесса составляет Общегосударственный план развития обычного высшего образования, призванный упорядочить структуру высших учебных заведений, надлежащим образом регулировать и развивать связи между обычным высшим образованием и высшим образованием для людей старшего возраста, средним специальным и начальным образованием, соответственно определять статус данных учебных заведений.

Комитет по делам образования придерживается концепции единого планирования в создании обычных высших учебных заведений, контролирует ускоренное плановое строительство обычных высших учебных заведений в провинциях, автономных районах в соответствии с потребностями общества.

Создаваемое обычное высшее учебное заведение должен возглавляют ректор и проректор, обладающие достаточно высокими политическими качествами, способностями руководить работой в области высшего образования, университетским дипломом, культурным уровнем, работать в вузе по основному месту работы.

В штате учебного заведения должны быть, кроме того, ответственные работники, занимающиеся по должности идейно-политической работой, ответственные работники на факультетах и по отдельным специальностям. ${ }^{15}$

При создании обычного высшего учебного заведения необходимо руководствоваться перечисленными ниже положениями, связанными с образуемыми в учебном заведении специальностями, нормами, численностью студентов и преподавателей:

1. В создаваемом университете или институте, а также ускоренном высшем учебном заведении или высшем профессиональном учебном заведении для обеспечения учебного процесса по каждой общей обязательной дисциплине и обязательной дисциплине основ специальности необходимо наличие

\footnotetext{
${ }^{15}$ Клепиков В.3. Современный Китай: вопросы воспитания // Педагогика. - 2000. № 5.
} 
по основному месту работы как минимум двух преподавателей, занимающих должности лекторов и выше; по каждой обязательной дисциплине специальности необходимо наличие по основному месту работы соответственно как минимум одного преподавателя, занимающего должность лектора и выше.

Число штатных преподавателей, занимающих должность ассистента-профессора и выше, должно составлять не менее 10 процентов общего числа специалистов-преподавателей в университете (институте) и 5 процентов в ускоренном вузе.

2. Число преподавателей-совместителей в университете или институте не должно превышать $1 / 4,1 / 3,1 / 2$ от числа преподавателей, работающих по основному месту работы в обычном вузе, институте, ускоренном вузе и высшем профессиональном учебном заведении, работающих по основному месту работы в данных заведениях.

При создании обычного высшего учебного заведения в соответствии с целями подготовки кадров, распределением по отраслям знаний, численностью, системой управления, местонахождением данного учебного заведения необходимо определить его статус.

Так, учебное заведение, именуемое университетом, должно отвечать следующим требованиям:

1. готовить в основном специалистов по объему полного курса;

2. иметь более 3 различных дисциплин в качестве основных в подразделениях по гуманитарным (включая литературу, историю, философию, искусство), политико-юридическим, финансово-экономическим, педагогическим (включая физкультуру), естественным, техническим, сельскохозяйственным и лесоводческим, медицинским наукам;

3. иметь достаточно сильные преподавательские и научно- исследовательские кадры, обеспечивать достаточно высокий уровень преподавания и научных исследований; насчитывать более 5 тыс. студентов, обучающихся на дневном отделении. Однако в отдаленных районах или в особых случаях с разрешения Государственного комитета по делам образования можно не придерживаться указанного ограничения ${ }^{16}$.

Учебное заведение, именуемое институтом, должно отвечать следующим требованиям:

1. готовить в основном специалистов по объему полного курса;

2. насчитывать более 3 тыс. студентов, обучающихся на дневном отделении.

Однако в институтах искусства, физкультуры и др., а также при стечении особых обстоятельств с разрешения Госкомитета по делам образования можно не придерживаться указанного ограничения.

Учебное заведение, именуемое ускоренным высшим учебным заведением, высшим профессиональным учебным заведением должно отвечать следующим требованиям:

1. готовить в основном специалистов по системе ускоренного высшего образования;

2. насчитывать более 1 тыс. студентов, обучающихся на дневном отделении.

Однако в учебных заведениях, расположенных в отдаленных районах, или при стечении особых обстоятельств с разрешения того же Госкомитета можно не придерживаться ограничения.

Законом "О высшем образовании» 1996 2. введено платное высшее образование в размере $\$ 500-$ 700 в год. Такая же сумма составляет плату за проживание в общежитии; ее устанавливает администрация провинции ${ }^{17}$.

Закон “О высшем образовании» 29.08.1998 2., принят на 4-ой сессии Всекитайского Народного собрания ${ }^{18}$ составлен на основе Конституции КНР и Закона об образовании. Все виды деятельности, касающиеся высшего образования, на сегодняшний день (на основе завершенного среднего образования) регулируются данным законом. В развитие социалистического высшего образования государство руководствуется учением марксизма-ленинизма, идеями Мао Цзэдуна и теорией Дэн Сяопина. Таким образом, высшее образование придерживается курса на социали-

16 Чжан Лили. Состояние китайского высшего образования // Высшее образование в России. - 2002. № 5. C.135.

${ }^{17}$ Боревская Н.Е. Китайская школа на пути в постиндустриальную эпоху // Мир образования - образование в мире. 2002. № 2. - C. 62.

${ }^{18}$ Вступил в силу с 01.01.1999 г. 


\section{Политика и общество 9 (105) • 2013}

стическую модернизацию, сочетание с производством и социалистической рыночной экономикой (ст.3-5). В соответствии с духом социалистического управления Государственный Совет КНР осуществляет единое руководство и управление делом высшего образования в стране (ст.12-14). Система высшего образования в данной стране включает в себя образование для академической и неакадемической квалификации. В первом случае оно делится на спецкурсы полной и сокращенной учебной программами, во втором спецкурсы учреждений неуниверситетского характера. Таким образом, единым органом - Государственным советом решаются все вопросы, начиная от создания вуза, разработки и утверж- дения его устава, назначения руководящего персонала и заканчивая ликвидацией.

Получение образования других уровней в Китайской народной республике осуществляется на платной основе, тогда как в промышленно развитых государствах высшее образование является так же общедоступным, как дошкольное, начальное и среднее общее образование, как, например, Закон «О высшем образовании» Франции.

С начала учебного 1999 г. введена система студенческого кредита. Бремя риска по кредиту возложено на физических лиц, гарантирующих банку возврат в размере 10,8 процентов годовых. Половину этой суммы возвращает государство в 4-летний сроки ${ }^{19}$.

Полисистемные правовые семьи (анализ законодательства социалистической и северной семей права на примере Китая, Республики Корея, Норвегии и Швеции)

\begin{tabular}{|c|c|c|c|c|c|c|c|c|c|c|}
\hline \multirow[t]{2}{*}{ Виды актов } & \multicolumn{9}{|c|}{ Виды отношений в образовании } & \multirow[b]{2}{*}{ 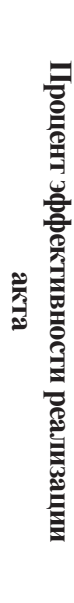 } \\
\hline & 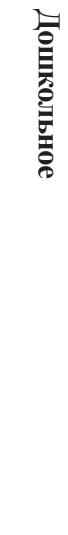 & 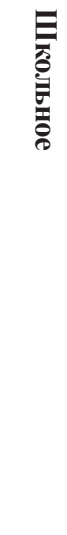 & 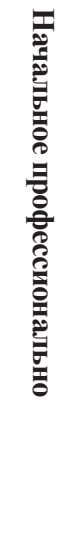 & 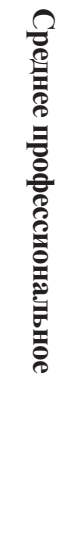 & 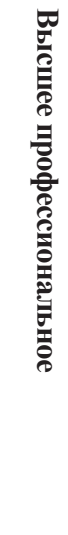 & 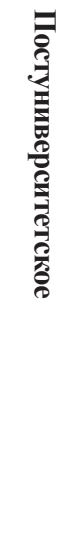 & 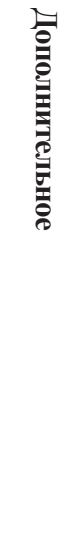 & 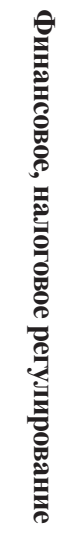 & 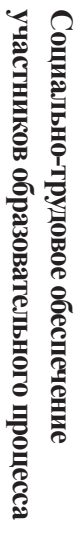 & \\
\hline \multicolumn{11}{|l|}{ Уровень высших государственных органов } \\
\hline Международные конвенции, соглашения, договоры & $\mathbf{x}$ & $\mathbf{x}$ & $\mathbf{x}$ & $\mathbf{x}$ & $\mathbf{x}$ & $\mathbf{x}$ & $\mathbf{x}$ & & & 50 \\
\hline Конституция страны & & $\mathbf{x}$ & & & $\mathbf{x}$ & $\mathbf{x}$ & $\mathbf{x}$ & $\mathbf{x}$ & $\mathbf{x}$ & 50 \\
\hline Закон страны (органический, обычный) & & $\mathbf{x}$ & & & $\mathbf{x}$ & $\mathbf{x}$ & $\mathbf{x}$ & $\mathbf{x}$ & & 60 \\
\hline Кодекс об образовании & & & & & & & & & & $\mathbf{0}$ \\
\hline $\begin{array}{c}\text { Постановление Распоряжения Правительства } \\
\text { (Директивы Национального Совета, Государственного }\end{array}$ & & & & & & & & & & 70 \\
\hline Совета по образованию) & $\mathbf{x}$ & $\mathbf{x}$ & $\mathbf{x}$ & $\mathbf{x}$ & $\mathbf{x}$ & $\mathbf{x}$ & $\mathbf{x}$ & $\mathbf{x}$ & $\mathbf{x}$ & \\
\hline
\end{tabular}

19 Реморенко И. Модернизация по-китайски: дешевый рынок для всех и дорогая свобода для элиты. // Педагогический Вестник № 7-8 (334-335) от 1-30 апреля 2004. 

решения министерских коллегий

(Белая книга)

\begin{tabular}{|llllllllll} 
& $\mathbf{x}$ & $\mathbf{x}$ & $\mathbf{x}$ & $\mathbf{x}$ & $\mathbf{x}$ & $\mathbf{x}$ & $\mathbf{x}$ & $\mathbf{x}$ & $\mathbf{x}$ \\
\hline Планы социально-экономического развития страны & $\mathbf{x}$ & $\mathbf{x}$ & $\mathbf{x}$ & $\mathbf{x}$ & $\mathbf{x}$ & $\mathbf{x}$ & $\mathbf{x}$ & & $\mathbf{7 0}$
\end{tabular}

\section{Уровень региональных государственных органов:}

Договоры и соглашения между исполнительными органами региональной власти по вопросам образования

Постановления региональных органов управления образования

Приказы министра образования субъекта, провинции

(инструкции ректора учебного округа, академии)

\section{Уровень местных органов государственной власти:}

Приказы распоряжения управлений образования, комитета по образованию муниципальных образований $\quad$ x $\quad$ x

Уставы муниципальных образований

Постановления и распоряжения главы муниципального образования

Договоры о разграничении полномочий между местными органами управления образования

Иные внешние договоры по вопросам регулирования образовательных отношений

$\begin{array}{lllllll}\mathbf{x} & \mathbf{x} & \mathbf{x} & \mathbf{x} & \mathbf{x} & \mathbf{x}\end{array}$

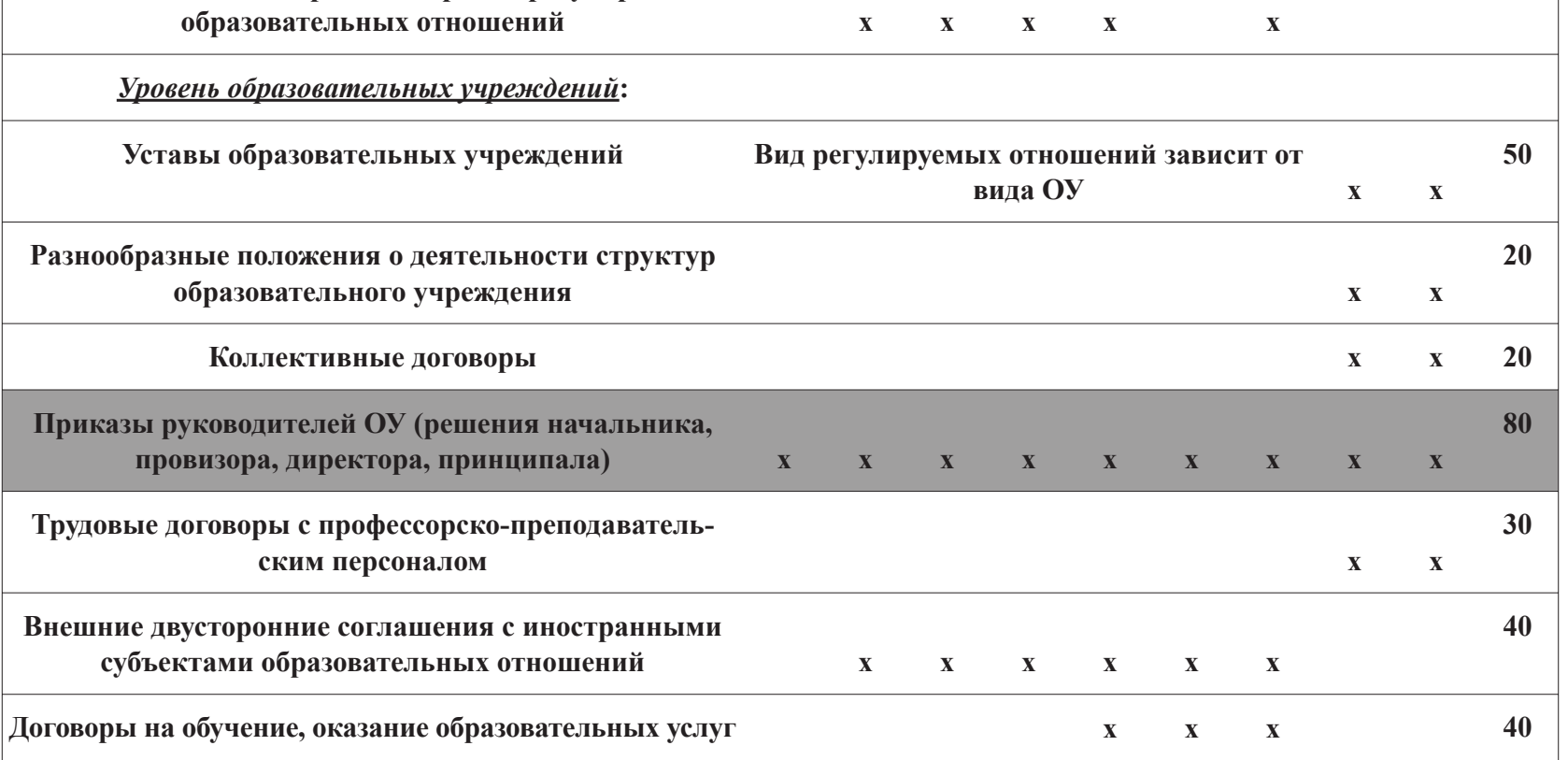




\section{Политика и общество $9(105) \cdot 2013$}

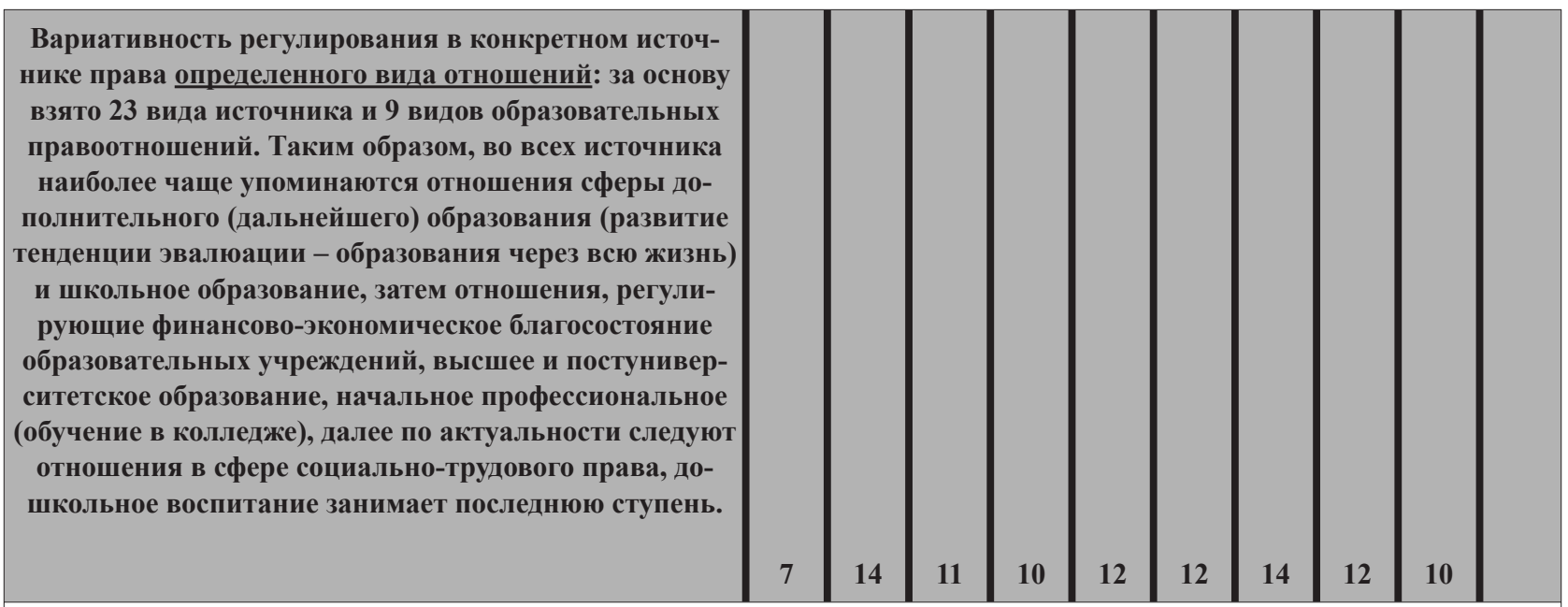

Самым распространенным источником права в данных правовых семьях с учетом поправки на выбранные страны и исходя из анализа нормативной литературы являются базовый и профильные законы об образовании и Планы социально-экономического развития страны, Постановления и Распоряжения Правительства

(Директивы Национального Совета, Государственного Совета по образованию), Доклады правительственных и министерских комиссии. Среди локальных нормативных актов принципиальное значение имеют Приказы руководителей образовательных учреждений (директоров школ, ректоров университетов)

\section{Библиография:}

1. Клепиков В.3. Развитие общеобразовательной школы КНР // Педагогика. - 1988. № 9.

2. Боревская Н.Е. Новые учебные программы в КНР // Советская педагогика. - 1993. № 3.

3. Жэньминь жибао. - 1985. 29 мая.

4. Боревская Н.Е. Управление образованиям в Китае // Педагогика. - 1996. № 11.

5. Чжунхуа жэньминь гунхэго гоуюань гунбао. 1986. № 12.

6. Реморенко И. Модернизация по-китайски: дешевый рынок для всех и дорогая свобода для элиты.// Педагогический Вестник. 1-30 апреля 2004. № 7-8 (334-335).

7. Путун цзяоюй гайгэ. - Пекин, 1987. - С. 36-72.

8. The Development of Education in China. 1988-1990. - Bejing, State Education Commission, 1990. - P. 10.

9. Unesco. Compendium of Statistics on Illite $\neg$ racy - 1990 Edition. P. 13, 25, 37; - Unesco. Statistical Yearbook, 1989. Table 1.3. P. 1-19.

10. Спецвыпуск журнала Вестник Нанкинского педагогического университета. - Нанкин, 1989. - С. 58.

11. Чжан Лили. Состояние китайского высшего образования // Высшее образование в России. - 2002. № 5.

12. Чжунхуа жэньминь гунхэго гоуаюань гунбао. 1987. № 4.
13. Клепиков В.3. Современный Китай: вопросы воспитания // Педагогика. - 2000. № 5.

14. Чжан Лили. Состояние китайского высшего образования // Высшее образование в России. - 2002. № 5. - С.135.

15. Боревская Н.Е. Китайская школа на пути в постиндустриальную эпоху // Мир образования - образование в мире. - 2002. № 2.C. 62 .

\section{References (transliteration):}

1. Klepikov V.Z. Razvitie obshcheobrazovatel'noi shkoly KNR // Pedagogika. - 1988. № 9.

2. Borevskaya N.E. Novye uchebnye programmy $\mathrm{v}$ KNR // Sovetskaya pedagogika. - 1993. № 3.

3. Zhen'min' zhibao. - 1985. 29 maya.

4. Borevskaya N.E. Upravlenie obrazovaniyam v Kitae // Pedagogika. - 1996. № 11.

5. Chzhunkhua zhen'min' gunkhego gouyuan' gunbao. - 1986. № 12.

6. Remorenko I. Modernizatsiya po-kitaiski: deshevyi rynok dlya vsekh i dorogaya svoboda dlya elity.// Pedagogicheskii Vestnik. 1-30 aprelya 2004. № 7-8 (334-335).

7. Putun tszyaoyui gaige. - Pekin, 1987. - S. 36-72. 
Человек и гражданин

8. Chzhan Lili. Sostoyanie kitaiskogo vysshego obrazovaniya // Vysshee obrazovanie v Rossii. - 2002. № 5.

9. Chzhunkhua zhen'min' gunkhego gouayuan' gunbao. - 1987. № 4.

10. Klepikov V.Z. Sovremennyi Kitai: voprosy vospitaniya // Pedagogika. - 2000. № 5.
11. Chzhan Lili. Sostoyanie kitaiskogo vysshego obrazovaniya // Vysshee obrazovanie v Rossii. - 2002. № 5. - S.135.

12. Borevskaya N.E. Kitaiskaya shkola na puti v postindustrial'nuyu epokhu // Mir obrazovaniya - obrazovanie v mire. -2002 . № 2. - S. 62 . 